ness formed in the Old World shaped behavior and action in the New. Other scholars, however, especially the French and U.S. labor historians, emphasized ethnicity's situational character and the extent to which individuals create ethnicity as one element of their working-class identity. These scholars were more interested in the interaction of workers of many ethnic backgrounds, especially in their new urban homelands. This disagreement never evolved - as it could have and sometimes has - into a simplistic disagreement over ethnicity versus class. But the tension between the approaches is far from resolution.

Recent changes in Europe provide an interesting backdrop to historical debates like these. Although the official language of the conference was English, many East European participants were more comfortable with German-another reminder of the influence of imperial pasts. Political change in the East allowed at least one participant to travel to a foreign conference for the first time. It also fueled lively and sometimes passionately contentious and multilingual explorations of past and present.

Overall, the wide-ranging and comparative aims of the conference brought suggestive, but not conclusive, results. By aiming so broadly, a number of important details remained vague. Many conference participants would have liked to hear more from the project researchers about the results of their research in Cleveland and Budapest. Even more, many wanted to learn more of the Bremen project's experience with collaborative research. For students of multiethnic working classes, collaborative research may be the only way to pursue comparison and synthesis without abandoning the full range of sources in many languages and countries. When queried, one project researcher noted, rather ruefully, that " "Conflict and Cooperation' said it all." Were Bremen researchers influenced by earlier collaborative efforts like the Philadelphia Social History Project? Did the Bremen research process replicate the tangled interethnic relations of workers in Cleveland and Budapest? Obviously, this was sensitive territory, where personality, ethnicity, and politics intertwined quite palpably with scholarship. If the Bremen group is to provide a model for others - as I believe it could - the research process itself, with all its warts, needs further explication and perhaps some outright analysis.

\title{
Perspectives on Labor History: The Wisconsin School and Beyond
}

\author{
Shelton Stromquist \\ University of Iowa
}

One hundred and seventy scholars and other persons interested in the current state of American labor history gathered March 9-10, 1990, for a conference at the State Historical Society of Wisconsin. The conference was organized as a joint venture 
of the Society, whose collections have long been a magnet for scholars in labor history, and the Department of History at the University of Wisconsin at Madison, which has until recently lacked a trained labor historian. The conference title suggested the multiple agendas the organizers brought to the undertaking. The program was designed to reflect on the Commons tradition, its influence on labor history, and its relevance to current work. The call for papers, however, solicited the widest possible array of topics. The resulting program was a mix of these agendas.

At the core of the conference were two papers delivered at plenary sessions. In "Reconciling the Old Labor History and the New," David Brody sought to define a common ground between them. He noted a new appreciation of the intellectual achievement of John R. Commons and Selig Perlman in making trade unions an object of serious study at a time when historians hardly gave them notice. $\mathrm{He}$ suggested that our current impasse with respect to "synthesis" relates very much to our inability to grasp fully the historical disjuncture in which the Commons school was born and the institutional legitimation it sought to give the labor movement in that historical context. Brody sees a reorientation in the field of industrial relations toward historically-grounded research that echoes the institutionalist origins of labor history in which Commons played such a decisive role. These neo-institutionalists are, in his view, forging important links to the Commons tradition. Finally, Brody argued that contemporary changes in the labor movement have led historians to reconsider the centrality of power relations and institutional developments in the past. This is particularly true of a host of new studies of twentieth-century unions and working-class communities.

In the second major paper of the conference, Leon Fink examined the origins of labor history in "Intellectuals vs. Workers: The Wisconsin School and the Creation of Labor History." Fink argued that labor history as a field of study was the self-conscious creation of intellectuals in the Ely-Commons school, whose project, in its various phases, reflected their own ambiguous and at times vulnerable positions as intellectuals. Selig Perlman, ever the outsider, placed intellectuals furthest from the creative core of the labor movement while constructing the most rigorous "theory" to account for its development. In Fink's view, we cannot understand the development of labor history without grasping the peculiar role of intellectuals who became its practitioners. Fink further argued that "new" labor historians, in their zeal to tell the story of American workers "from the bottom up," have largely failed to account for the role of intellectuals in the story itself or to reflect on their own role as intellectuals in its reconstruction.

Reflection on the legacy of the Commons school was a theme in two other sessions. Three papers explored connections between public policy and the work of the Commons/Wisconsin school: H. M. Gitelman, "Commons vs. Walsh: The Disputed Path of Public Policy Toward Labor"; Daniel Ernst, "The Anti-Trust Challenge to Industrial Democracy, 1908-1932"; and Clarence Wunderlin, "Labor Relations and the Law: The Wisconsin School, Administrative Government, 
and the Commission on Industrial Relations, 1913-1916." Another session explored what might be termed the "new" institutional history of American labor and specifically of the American Federation of Labor. Papers by Julia Greene, Kenneth Fones-Wolf, and Dorothee Schneider reexamined aspects of the AFL's history in ways that suggested greater diversity of views and practices in politics and trade-union policy than is generally acknowledged.

Other sessions focused on diverse topics and themes that reflect current directions of scholarship. The complex and conflicted relationship between organized labor and the NAACP was explored by John Bracey and August Meier, with spirited comments by participant Herbert Hill. Two sessions focused on regional or local aspects of labor history: western workers and the "hidden history" of Milwaukee's labor and socialist movement. Others examined particular groups of workers: farm laborers, packinghouse workers, and workers in the textile and steel industries.

A prominent feature of the program was a group of sessions that explored the relations between the labor movement and the left. In a session on "Communism and the CIO," papers by Steven Rosswurm, Ellen Wolf Schrecker, and Martin Halpern examined the role of communists as an important force within the CIO unions. Papers by Shelton Stromquist, James Barrett, and Peter Rachleff examined continuities and discontinuities in twentieth-century labor radicalism through three cases: the role of militant street car strikes in shaping Cleveland's municipal progressivism at the turn of the century, the rise and decline of Chicago's radical labor movement between 1900 and 1922, and the formation and dissolution of the Independent Union of All Workers as a unique expression of 1930s labor radicalism in Austin, Minnesota.

The organizers of the program made some effort to give attention to issues of gender and race. Nine papers and three sessions focused on workers of color and five papers in two sessions had women workers as their primary subject. A session on "theories of labor history," however, largely failed to engage issues of class formation and the social construction of gender, race, and ethnicity that are at the center of current controversies. The papers at best probed the margins of these essential theoretical debates.

In the eyes of this reporter, the conference served a useful purpose in providing another forum for the presentation of new and often exciting research on subjects that continue to be extraordinarily vital. But it did not manage to create an opportunity to engage on a critical level the current historiographical and theoretical controversies labor historians face. The conference, for the most part, did not confront the growing differences in a manner that clarifies their theoretical implications or suggests the outlines of coherent and persuasive alternative syntheses. Calls for "reconciliation" and the reintegration of labor history and industrial relations seem largely to abandon what was most original and promising in the new labor history - its emphasis on culture and class experience in diverse workplace and community settings. Synthesis must build on the diversity of class 
experience that labor historians continue to document in rich detail by integrating a more precise understanding of the interplay of corporate power, state intervention, and political reform with class forces in different periods. For the moment, at least, we have not moved very far down the paths of alternative syntheses. Yet the conference call, for all of its ambiguity, and the reappearance of the State Historical Society of Wisconsin as a center stage for labor historians to present their work, suggested the possibility for more.

\title{
The Formation of Labor Movements, 1870-1914: Comparative Perspectives
}

\author{
Wayne Thorpe \\ McMaster University
}

Few conferences have had foundations as well-laid as that held at Alkmaar, The Netherlands, May 31-June 2, 1990. The sponsor, the International Institute of Social History (IISH), Amsterdam, had coordinated and distributed to delegates twenty-seven national case studies of developing labor movements ${ }^{1}$ as a basis for discussion and for the formulation of comparative research proposals, which delegates submitted prior to the conference.

The conference opened by considering trends in labor history. Formal reports for the major nations were presented by John Saville and Richard Price, Britain; Shelton Stromquist and David Montgomery, United States; Yves Lequin and JeanPaul Burdy, France; Bruno Naarden, Soviet Union; Klaus Tenfelde, Germany. These elicited a good deal of somber stocktaking, especially during informal discussions; a number of delegates joined Klaus Tenfelde in describing the "crisis" in labor history. Many concerns found expression: a steady decline in the proportion of workers in the population; the distaste associated with labor history in Eastern Europe; ebbing student interest elsewhere; a weakening infrastructure, with declining funding, few jobs, and a weak book market; the fragmentation of inquiry that artificially divides labor, gender, ethnic, and racial studies; the limitations of purely local studies; and the lack of new methodologies and uncertainties about new directions.

On the second day, the conference moved to issues of comparative history, with two examples of analysis and two of methodology. Friedrich Lenger (FRG) compared class formation in its artisanal phase (which ended between 1850 and 1880 ) in England, the United States, France, and Germany. Analyzing occupational traits (especially among tailors, shoemakers, and cabinetmakers) and the presence or absence of guild or other artisanal corporative influence, Lenger challenged the notion of a common development of labor movements. Viewing the 